\title{
VOL. XXIX.-I9I4.
}

THE

\section{JOURNAL OF LARYNGOLOGY,}

RHINOLOGY, \& OTOLOGY;

\author{
A RECORD OF CURRENT LITERATURE
}

RELATING TO

\section{THE THROAT, NOSE, AND EAR.}

PUBLISHED MONTHLY.

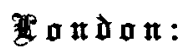

ADLARD AND SON, BARTHOLOMEW PRESS BARTHOLOMEW CLOSE, E.C.

RNTFRED AT STATIONRR' haLio. 


\section{THE JOURNAL OF LARYNGOLOGY RHINOLOGY; AND OTOLOGY.}

Founded in 1887 by MORELL MACKENZIE and NORRIS WOLFENDEN.

\section{Editorial Committeg :}

A. H. Chentue, F.R.C.S.

(Pres. Otol. Sect. Internat. Cong.).

Dundas Grant, M.A., M.D., F.R.C.S. (London). Albert A. Gray, M.D. (Glasgow)

William Hili, M.D. (London). (Pres. Otol. Sect. R.S.M.).

(Pres, Laryng. Sect. R:S.M.).
J. Macintyre, M.B., C.M., (Glasgow).

Sir W. Miluigan, M.D., M.Ch. (Manchester).

Sir StClair Thomson, M.D., F.R.C.S. (London)

(Pres. Laryng. Sect. Internat. Cong.).

Logan Turner, M.D. (Edinburgh).

P. Watson-Williams, M.D. (Bristol).

Macheod Yearsley, F.R.C.S. (London).

EDITor :

Dan McKenzie, M.D., F.R.C.S.E. (London).

WITH THE CO-OPERATION OF THE STAFF OF ABSTRACTORS:

Drs. J. Stoddart Barr (Glasgow), H. S. Birkett (Montreal), Brady (Sydney, N.S.W.), John Darling (Edinburgh), Donglan (London), Clayton Fox (London),

J. S. Fraser (Edinburgh), Perry Golosmith (Toronto),

Thos. Guthrie (Liverpool), A. Hutchison (Brighton), J. D. Lithaow (Edinburgh), A. MCCall (Bournemouth), Chichele Nourse (London), W. G. Pokter (Edinburgh),

Price-Brown (Toronto), Knowles Renshaw (Manchester),

Lindley Sewell (Manchester), Alex. R. Tweedie (Nottingham),

Raymond Verel (Aberdeen), C. E. West (London), G. Harold L. Whale

(London), Wrieht (Bristol), and WyLie (London).

AND THE ASSIBTANCE OF

Mr. George Badaerow (London), Drs. J. Barr (Glasgow), Hugo Frey (Vienna),

Grazzi (Florence), Middegmass Hunt (Liverpool),

A. Brown Kelly (Glasgow), E. Law (London), Massei (Naples),

D. Paterson (Cardiff), Urban Pritchard (London), F. A. Rose (London),

A. SAndford (Cork), Sendziak (Warsaw), H. Tilley (London),

E. WAGGETT (London), R. Woods (Dublin). 


\section{LIST OF PLATES.}

To illustrate Dr. Urban Pritchard's Article on Extra Maculat FOUND IN THE AMPULle OF SOME BIRDS. .

Fig. 1.-Section of the Macula acustica of the Saccule of the Cat. $\times 200$ DIaM.

Fig. 2.-Section of the Nightingale's Amptllat Region. Fig. 3.-Another Section throvgh the Fan-Shaped Body.

To illustrate Dr. A. Logan Turner's article on a Peculiar Form of Hyperplasia of the Mucous Membrane of the UPPER Respiratory Tract.

Plate I-Coloured Plate of the fauces and Pharynd Plate II, Fig. 1.-Black and White Sketch of the Fauces and Pharynx

Fig. 2.-The Upper Laryngeal Aperture.

Plate III, Fig. 3.-Microscopic Section of Mucous SurFACE. $\times 60$ DIAM. .

Fig. 4.-The Same. $\times 200$ diam.

Intra-nasal Operations for Frontal Sinus Suppuration. P. Watson-WILliams.

Plate I, Fig. 1.-To show the Point of Emtry in the Intra-nasal Frontal Sinus Operation

Frg. 2.-To show the Author's Small Spheno-ethmoidal FORCEPS.

Fig. 3.-The Sliding Cutting Forceps Reducing the Crista Nasalis.

Plate II, Fig. 1.-Shiagram showing the 6 Mm. Thick Bougie entering Frontal Sinus.

Fig. 2.-The Same, showing the 6 mm. Bougie.

Fig. 3.-Lateral View of Frontal Sinus and Swan. HEAD BOUgIE.

Fig. 4.-The Same, Antero-posterior Aspect.

Plate III, Fig. 1.-Large Bougies in Both Frontal Sinuses (Skiagram)

Fig. 2.-Skiagram showing Endo-Rhinoscope in Frontal Srnus.

Fig. 3.-The Guarded Electric Burr reducing the Crista Nasalis.

Fig. 4.-The 6 mm. Burr on Nasal Crest. 
The Intra-nasal Treatment of Empyema of the Frontal Sinus. HERBERT TILLEY.

Plate I, Fig. 2.-Lateral Wall of Nose showing Aggar Cell and Frontal Sinus . : .

Fig. 3.-Laterat Wall of Nose showing Aggar Cell aNd ETHMOIdal BULLA.

Plate II, Fig. 4.-Site of Access to Anterior Grodp of Ethmoidal Cells . . .

Fig. 5.-Ethmoidal Region with Removal of Anterior Cells.

Acute Suppurative Otitis Media, Purulent Labyrinthitis and Leptomeningitis without Rupture of the Tympanic Membrane. J. S. Fraser.

Plate I, Fig. I.-Horizontal Section throvgh Normal Left Ear of Infant in Region of Oval Window .

Fig. 2.-Horizontal Section throdgh Left Ear of Present Case about same Level as Fig. 1.

Fig. 3.-Horizontal Section throdgh Normal Left Ear of INFANT in REgion of Round Window.

Fig. 4.-Horizontal Section throdgh Left Ear of Present Case about Same Level as Fig. 3.

Plate II, Fig. 5.-Horizontal Section through Left Ear of Present Case.

Fig. 6.-Ditio.

Frg. 7.-Ditio.

Fig. 8.-DitTo.

(Fach Figdre showing different Structures.)

Plate III, Fig. 9.-Horizontal Section throvgh Right Ear of Present case

Fig. 10.-Ditto.

Fig. 11.-Ditro.

Fig. 12.-Ditto.

(Fach Figure showing different Structures.)

Suspension Laryngoscopy and its Practical Use. G. Killian.

Fig. 31.-The View in Suspension Laryngoscopy. EpiGLOTTIS EXPOSED .

Fig. 32.-Ditto. The Larynx exposed.

Diathermy in the Treatment of Inoperable Growths of the Nose and Throat. W. D. Harmer.

Fig. 1.-Cancer of LarynX, before Treatment

Fig. 2.-Cancer of Palate, before Treatment.

Fic. 3.-Ditto. After Treatment. 


\section{ILLUSTRATIONS IN TEXT.}

Tumour of Soft Palate consisting Mainly of Salivary Gland

Tissue. Thos. Guthrie.

Fig. 1.-VIEW OF FAUCeS $\quad . \quad . \quad . \quad . \quad 69$

Fig. 2.-Section throdgh the whole TUMOUR. $\times 5$. 70

Fig. 3.-SECtion OF PaRt OF the Tumour. $\times 200 \quad 70$

Note ON THE TeChNiqUe OF ThE INTRA-NASAL Operation For

Antral Sinus Suppuration. P. Watson-Williams.

Fig. 1.-Punch Forceps . . . . 114

Fig. 2.-Drawing to show the Author's Intra-nasal Antral Operation . . . . . 115

The Intra-nasal Treatment of Lachrymal Disease. D. $R$. Paterson.

Fig. 1.-Sections showing the Relations of the Lachrymal Fossa and Naso-lachrymal Duct . .

Fig. 2.-Frontal Section of Preparation. a. Anterior Segment. B. Posterior Segment . . . 171

Fig. 3.-Dissection showing Parts about Lachrymal SAC AND DUCT . . . . . . . 172

Fig. 4.-Skiagram of Style which had been passed through the Sac-wall into the Midde Meatus . 175

Fig. 5.-Diagram of Lachrymal System to Illugtrate Principle of Operation . . . . . 176

Fig. 6.-Operation as done by West . . . 178

Fig. 7.-Elevator of Muco-periosteal Flap and Chisels 179

Fig. 8.-Fine-Toothed Forceps . . . . $\quad 179$

Note on the Histology of Enucleated Tonsil. Wyatt Wingrave.

Fig. 1.-Section through the Bed of the Tonsil . 182

Fig. 2.-The Same stained to show Elastic Fibres . 182

Fia. 3,-Section to show Elastic Fibres . . 183

a New Theory of Hearing. F. P. Sturm.

Fig. 1.-Hair Cells . . . . 194

Fig. 2.-Diagram illustrating the Silent and the SOUND-ADAPTED EAR $\quad . \quad$. $\quad . \quad . \quad . \quad 195$

Intra-nasal Frontal Sinus Operation. P. Watson-Williams.

Method of entering and OPENING UP FRONTO-EThMOIDAL Celle . .

Intra-nasal Operations for Frontal Sinus Suppuration. P. Watson-WiLliaMS.

Fig. 1.-Sullivan's Raspatories . . . 227

Fig. 2.-Segura's Raspatories and Curettes . . 229

Fig. 3.-Diagram of Ethmoidal Labyrinth and FrontomThmotdal Cells . 
Fig. 4-Bone-specimen showing the Fronto-nasal Pas-

Fig. 5.-The Author's Spheno-ethmoidil Angular For-

PAGE C.es

Fig. 6.-The Sliding Cutting Forceps.

Fig. 7.-The Author's Guarded Electric Burge

Fig. 8.-The Author's Frontal Sinus Bougies.

Fig. 9.-The Author's Small Raspatory

Fig. 10.-The Author's Frontal Sinus Cannule

Fig. 11.-Diagram to illustrate the Point of Entry of CuretTe

Fig. 12.-Diagram showing Muco-periosteal Flap 231 233 233 $\mathbf{2 3 3}$ 233 235 237

The Intra-nasal Treatment of Empyema of the Frontal Sinus. Herbert Tilley.

Fig. 1.-Lateral Wait of Nose

The Rhinogenic and Otogenic Lesions of the Third, Fourth, Fifth, and Sixth Cranial Nerves. Ladislaus Onodi.

Fig. 1.-Gasserian Ganglion and Sphenoidal Sinds . 308

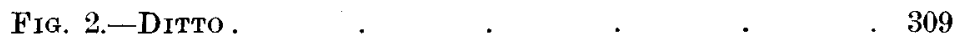

Fig. 3.-Second Division of the Trigeminus and the Sphenotdal Sinus . $\quad . \quad$. $\quad . \quad 310$

Fig. 4.-Sphenoldal Sinus and Neighbouring Nerves . 311

Fig. 5.-Sphenoidal Sinus and Abducens . . 312

Fig. 6. Sphenoidal Sinuses . . . . 361

Fig. 7.-Sphenoidal Sinus, Foramen Rotundum, and Superior Orbital Fissure.

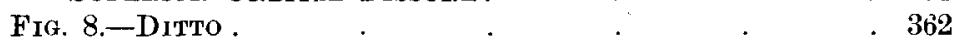

Fig. 9.-Frontal Sinus and Superior Orbital Fissure . 363

Fig. 10.-Sphenoidal Sinus and Vidian Canal . • 364

Fig. 11.-Apex of Petrous Bone and Sixth Nerve • 367

Suspension Laryngoscopy and its Practical Use. G. Killian.

Fig. 1.-View with Suspension Laryngoscopy in the

Gadaver .

Fig. 2.-Spatula Hook in its Earliest Form . $\quad .339$

Fig. 3.-Gutter-SPatula . . . . 342

Fig. 4.-Flanged Gutter-spatula $\quad . \quad$. $\quad$. 343

Fig. 5.-Double Spatula $\quad$. $\quad . \quad 343$

Fig. 6.-Double Spatula with Epiglottis Elevator . 344

Fig. 7.-Suspension HoOK . . . . . . 345

Fig. 8.-Mouth Gag . . . . . . . . $\quad$. 346

Fig. 9.-Suspension Hook with Modth-gag . $\quad .346$

Fig. 10.-Suspension Hook, etc., Seen from Side $\quad 347$

Fig. 11.-Coun'ter-PRESSOR . . . . 348

Fig. 12.-COUNTER-PRESSOR EXTENDED . . . 349

Fig. 13.-Suspension Hook with Spatula and Counter-

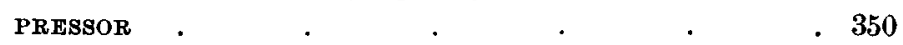

Fig. 14.-The Gallows . . . . . . 351

Fig. 15.-Operating Table lowered $\quad$ - 352

Fig. 16.-Operating Table RaIsed . . . 353 
Fig. 17.-Operating Table. Head aspect . . 354

Fig. 18.-Operating Table. Head Support . 355

Fig. 19.-Suspension Hook, etc., on Operating Table . 356

Fig. 20.-Glass Protector on Gallows. . 357

Fig. 21.-Operating Instruments . . . . 357

Fig. 22.-Fischer's Clip Holder . . . 358

Fig. 23.-Wolff's Head Lamp . . . . 358

Fig. 24.-Transformer with Head Lamp . . 359

Fig. 25.-WATER Suction Air-pump . . 359

Fig. 26.-LAMP FOR GAG . . . . 360

Fig. 27.-Handle for Tongue Spatula. . . 394

Fig. 28.-Bradn's Bellows Apparatus . . . 394

Fia. 29.-Introduction of Suspension Hook . . 396

Frg. 30.-Suspension Laryngoscopy . . . 397

Fig. 33.-Three Chanelled Bronchoscopy Tube . 402

Fig. 34.-Three Chanelled Tube, etc. . . 403

Fra. 35.-Suspenston Bronchoscopy . . . 404

Fig. 36.-Albrecht's Hot-air Box . . . 406

Fig. 37.-Application ow Mesothoritom . . 408

A Case of Paralysis of the External Rectus Muscle due to the Presence of an Abscess in the Apex of the Petrods Pyramid, etc. Geo. Wilkinson.

Fra. 1,-Temporal Bone viewed from above . . 412

Fig. 2.-Section through Temporal Bone . . 413

Br-submuoous Resection of Septum Nasi. J. V. D. H. Leonhard.

Illustrating the Operation . . . . . 420

Diathermy in the Treatment of Inoperable Growths of the Nose and Throat. W. D. Harmer.

Fig. 4.-Navus of Face. Before Treatment . . 484

Frg. 5.-Ditto. After Treatment . . . 485

ON the Minimizing of Hamorkhage in Extirpation of the Tonsils, etc. Wm. Hill and G. J. F. Eldphick.

The Elphick Hemostatic Guillotine . . . 549 


\section{INDEX 'T'0 VOLUME XXIX, 1914.}

\section{SUBJECTS.}

Abductor paralysis, see Cord, vocal.

Acoustic tracts, subsidiary (A. Kreidl)

Adductor paralysis, see Cord, vocal.

Adenoids, effects of (O. Paget)
- operation on, results (W. Wilson, F. Warmer) trauma from (H. L. Whale)

Adrenalin in treatment by salvarsan.

Air-passages, upper, diseases of, vaccine treatment of (D. Harmer)

- plasmacytoma of (H. Wachter) W. Richardson) ${ }^{\cdot} \quad \cdot 391$

American Laryngological Association, proceedings of the . $\quad 45$

- Rhinological, and Otological Society, proceedings of the

$39,100,379$

Anrsthesia, ethyl chloride and respiratory stoppage (J. D. Lithgow) $\quad 92$ general, a new method of (W. Freudenthal) . . 447 Local, Text-book of, by Prof. Dr. George Hirschel (review, D. McKenzie)

Anmethetics, by Dudley ir. Buxton (reviev, • Antroscope, maxillary (Dan McKenzie)

Antrostomy, nasal (P. Watson-Williams, O. Levinstein)

Antrum, maxillary, endothelioma of (A. Brown Kelly) . $\quad 471$ - epithelioma of (W. Stuart Low) .506

- operation on, intranasal technique of (P. Watson-Williams)

Kelly) puncture of, dangers of (Killian, H. M. Bowen, Brown

Aphonia, congenital syphilitic laryngitis (W. H. Jewell) $\quad . \quad 159$

Arytænoid, fixation of (S. H. Mygind, G. Wilkinson) $\quad \cdot \quad$ 331, 331

Asthma and its Radical Treatment, by Jas. Adam (review, P. Watson-

Williams)

Atrophic rhinitis, see Rhinitis, atrophic.

Atropin, effect on voice (Cisler) . . 166

Auditory centre, localisation of (Boyd and Hopwood) $\quad$. $\quad$. 479

- nerve, division of the, for tinnitus (C. H. Frazier) . . 222

Auricle, see also Ear, external. tumour of the (J.S. Fraser)

Bone-conduction in syphilis (Oscar Beck) . . . . 388

Brain, abscess of, see Brain, temporo-sphenoidal lobe of, and Cerebellum. acoustic tracts in (A. Kreidl) 
Brain, operative trauma of, recovery (Dan McKenzie)

temporo-sphenoidal lobe of, abscess of (W. G. Porter, J. Kerr

Love, H. L. Whale) .

British Medical Association, The, Section of Oto-Laryngology, meeting at Aberdeen July, 1914 . 279

-7 proceedings of the $481,487,496,513,520,524,532,576$

Bronchial calculus (W. F. Chappell)

45
.$\quad 45$
79,

\begin{tabular}{llr} 
Broncholith (W. F. Chappell) & 45 \\
Bronchus, foreign body in (D. R. Paterson) & $:$ & $\mathbf{7 9 ,} 147$ \\
\hline
\end{tabular}

Carbolic acid and glycerine for turbinal hypertrophy (J.D. Lithgow and

Peel Ritchie)

Cavernous sinus, see Sinus, cavernous.

Cerebello-pontine angle, tumour of (J. S. Fraser, W. M. Mollison)

Cerebellum, see also Brain. abscess of (W. Milligan, H. Whitehouse and J. G. Galbraith) 142, 441

- 1 a new symptom of (M. Mann) 446

$\longrightarrow$ multiple operation, recovery (C. E. West) $\quad . \quad$. 312

Cerebro-spinal rhinorrhoea (P. Watson-Williams and discussion) : 82

Cholesteatoma, large (N. Maclay) . . . . . . 470

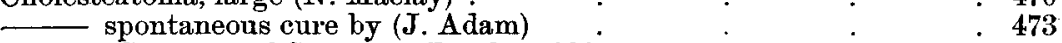

Clinical Congress of Surgeons, London, 1914 $\quad . \quad \therefore \quad .327$

Colds in the head (L. Hill and F. F. Muecke)

"Compendium of the Pharmacopoias and Formularies," by C. J. S. Thompson, review (Macleod Yearsley).

Cord, vocal, see also Larynx and laryngeal nerve.

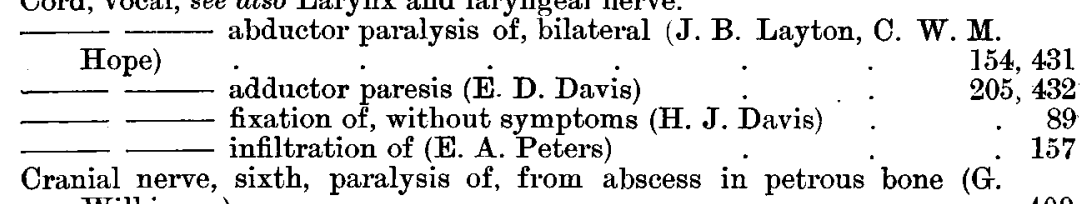

Wilkinson) 409

nerves, third, fourth, fifth and sixth, rhinogenic and otogenic
lesions of the (L. Onodi)

Crico-arytrenoid joint, theumatism of (S. H. Mygind) $\quad$ : $\quad$. 331

Dacryocystotomy, intranasal (L. Polyák, D. R. Paterson) 48, 169, 423

Deaf-mutism, prevention of (Macleod Yearsley)

Deafness, aids to bearing in (W. S. Bryant, G. J. Jenkins) : $\quad$ 12, 523

\begin{tabular}{cc}
- \\
\hline associated with Bárány's symptom complex (Bárány) : & 2 \\
\hline
\end{tabular}

\begin{tabular}{lll}
\hline caisson workers (G. W. Boot) & $\cdot$ & 600 \\
\hline
\end{tabular}

— fracture of skull causing (W. M. Mollison) : $\quad: \quad:{ }_{23}$

_._ from gun fire (Jobson Horne)

increased bone-conduction in obstructive, theories of (Heschl) $\quad .332$

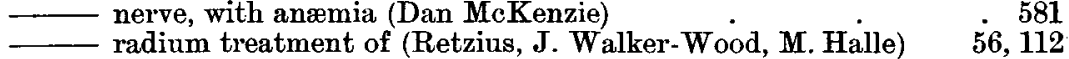

- re-education treatment of (A. Raoult, H. Lavrand, R. Lake, J.

Mackenzie Booth, F. F. Muecke) $\quad \cdot$ 108, 109, 111, 318, 466, 524, 543

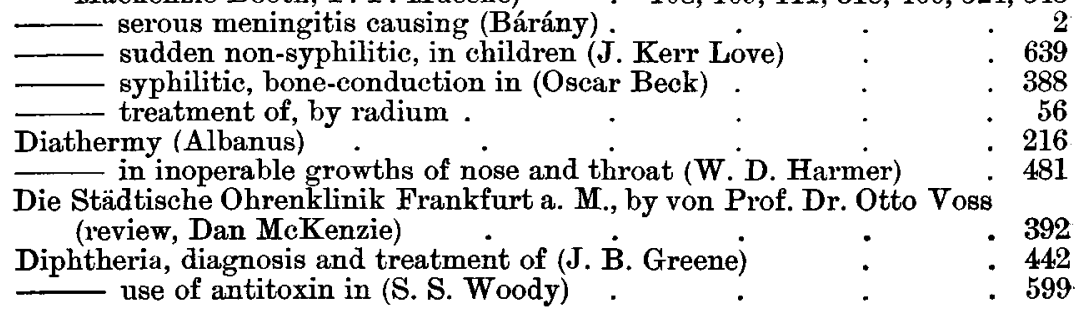


Diseases of the Nose, Throat and Ear, by Francis R. Packard, M.D., (review, $\mathbf{P}$. Watson-Williams)

- of the Ear, by Philip D. Kerrison (review, Macleod Yearsley) $\quad . \quad 55$

Dura mater, operative trauma of, in middle turbinotomy (Kümmel) : 216

Dysphagia from eventratio diaphragmatica (Marx)
-

Ear, atrophy of (N. Sack) _ . . . 511

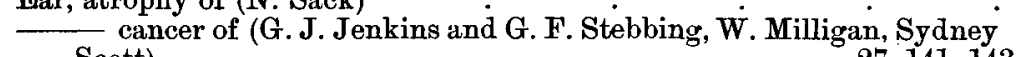

Scott) . . . . . 2 . 27, 141, 143, 585

cholesteatoma of (N. Maclay)

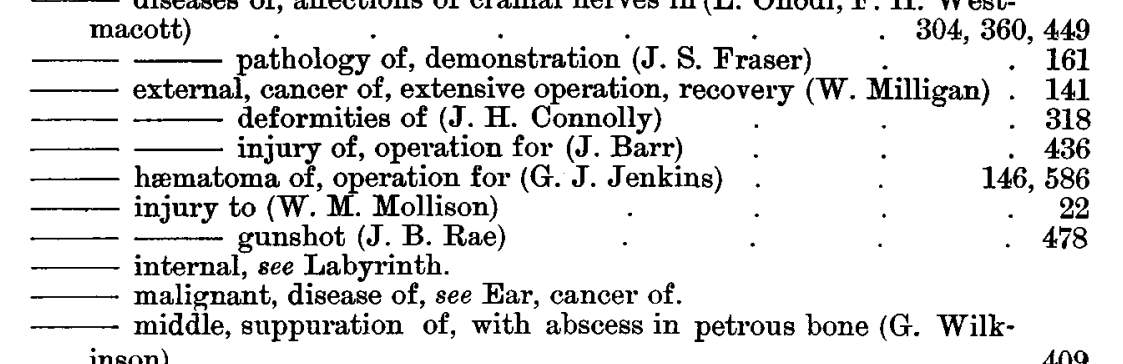
macott)

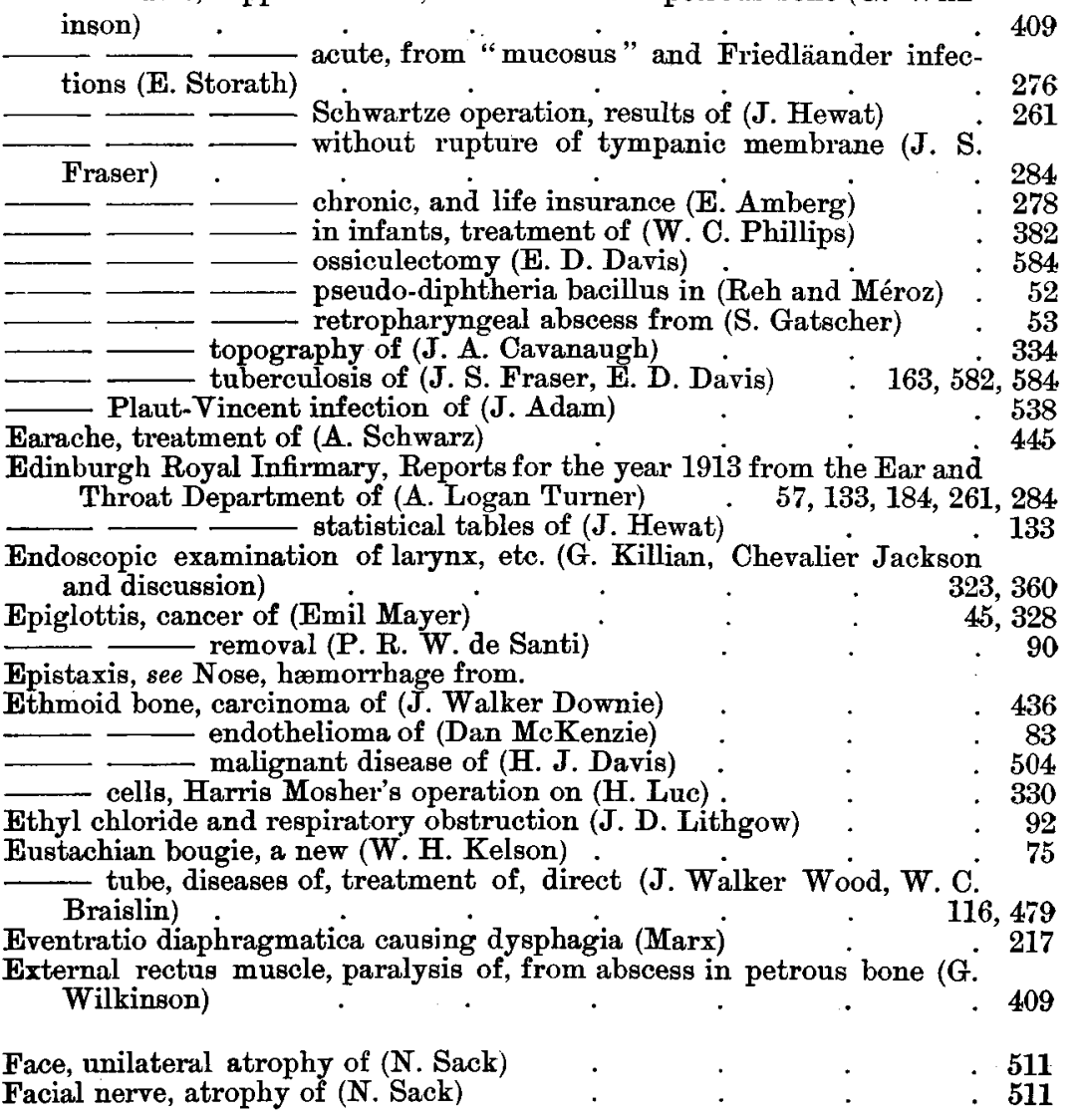


Fifth Nerve (Trigeminus), Map Scheme of the Sensory Distribution of the, etc., by L. Hemington Pegler (review, Dundas Grant) . $\quad 109$

Foreign bodies, colour of, hindering discovery of (D. R. Paterson) : 147

Frontal sinus, see Sinus, frontal.

German Laryngologists, The Proceedings of the Society of, 1913

Geschichte der Ohrenheilkunde, by Dr. Adam Politzer (review, Dundas Grant)

Goitre, see also Thyroid gland.

congenital (S. Pern) with severe pressure symptoms (Dan McKenzie)

Hæmatoma auris see Ear.

Hæmorrhoids and bulbar tonicity (P. Bonnier) . $\quad . \quad$. 384

Hay fever, ætiology of (A. Coolidge, T. Smith) $\quad \cdot \quad \cdot \quad \quad .50$

- treatment of (H. L. Ulrich)

- vaccine treatment of (A. G. H. Lovell) $\quad: \quad 219$

Haynes' operation for meningitis (E. W. Day, E. D. Dench) : $\quad 100,222$

Hearing, test for (M. Kabatschnik) _ . $\quad$. $\quad .51$

Heart, valvular disease of, and recurrent paralysis (Killian, Sobernheim 193

and Caro) . $\quad . \quad 2 \quad . \quad 215,219$

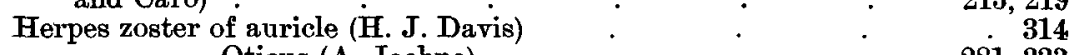

Hoarseness from Oticus (A. Jaehne) $\quad \cdot \quad \cdot \quad 281,333$

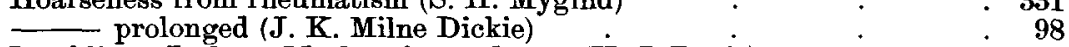

Hughlings Jackson-Mackenzie syndrome (H. J. Davis) $\quad: \quad \quad{ }^{\circ} \quad 3_{2}$

Hyperostosis cranii (H. Lambert Lack) $\quad \cdot \quad \cdot \quad \cdot \quad 30$

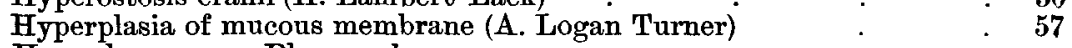

Hypopharynx, see Pharynx lower.

Hypophysis, see Pituitary body.

Insurance, life, and middle-ear suppuration (E. Amberg) . $\quad 278$

International Collective Investigation of Ozæna (A. Brown Kelly) $: 255$

International Congress of Medicine, Reports of, Section of Laryn-

$$
\begin{array}{llll}
\text { gology } & . & &
\end{array}
$$

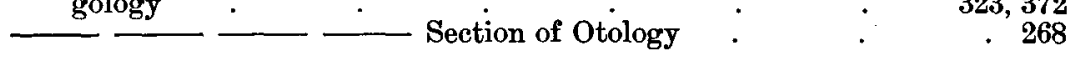

Jaw, see Maxilla.

Kinesiphone, Maurice's (J. Mackenzie Booth)

Labyrinth, see also Cochlea, Semi-circularcanals and Vestibular apparatus.

anatomy of, in birds (Urban Pritchard)

- operation on the, see Labyrinthotomy.

sequestrum of the (E. P. Fowler)

syphilis of the (O. Glogan)

Labyrinthitis, (E. P. Fowler)

Labyring (J. G. Connal)

—_ literature of (J. S. Fraser)

recovery from, without labyrinth operation (F. W. Bennett and

Dan McKenzie)

\begin{tabular}{l} 
serous (J. S. Fraser) \\
symptoms of, in suppuration of ear (J. S. Fraser) \\
\hline withont rupture of tympanic membrane (J. S. Fraser)
\end{tabular}

withont rupture of tympanic membrane (J. S.

- 220

- 439

Lachrymal apparatus, intra-nasal operations on (L. Polyák, D. R. 
Lachrymal organs, Relation of the, to the Nose, etc., by Prof. Dr. A. Onodi (review, P. Watson-Williams)

Laryngeal nerves, recurrent, paralysis of (W. H. Kelson, J. Walker Downie)

and Caro)

Das)

recurrent, paralysis of, from lymphomatous glands (H. J.

Davis) - - from esophageal cancer (E. A. Peters)

Donelan) superior, paralysis of, from disseminated sclerosis (J. (Wressure on, for tuberculous dysphagia (Rethi)

Laryngectomy, speech after (E. W. Scripture)

Laryngitis, chronic (A. Wylie)

congenital syphilitic (?) (W. H. Jewell)

Laryngo-fissure, see T'hyrotomy.

Laryngoscopy, autoscopic (Panconcellia-Calzia)

autostatic (Robert-Leroux)

direct, a new method (Katzenstein)

suspension (E. D. Davis, M. Mayer, G. Killian, W. Freudenthal)

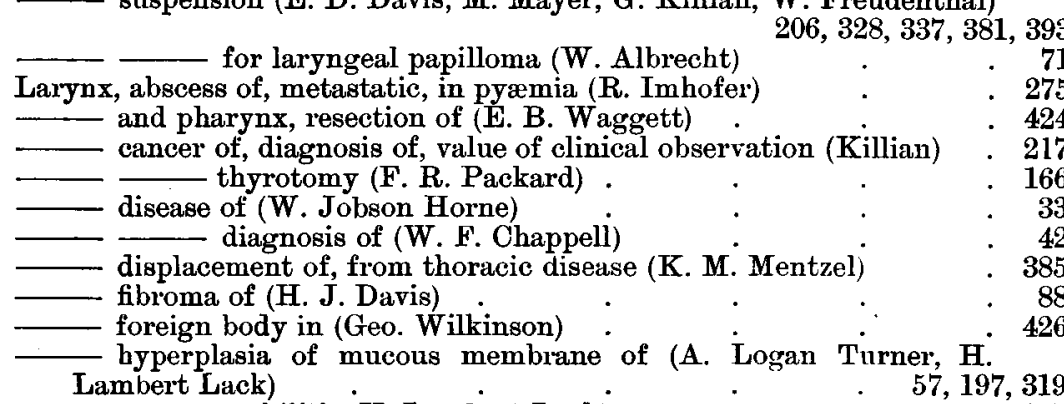

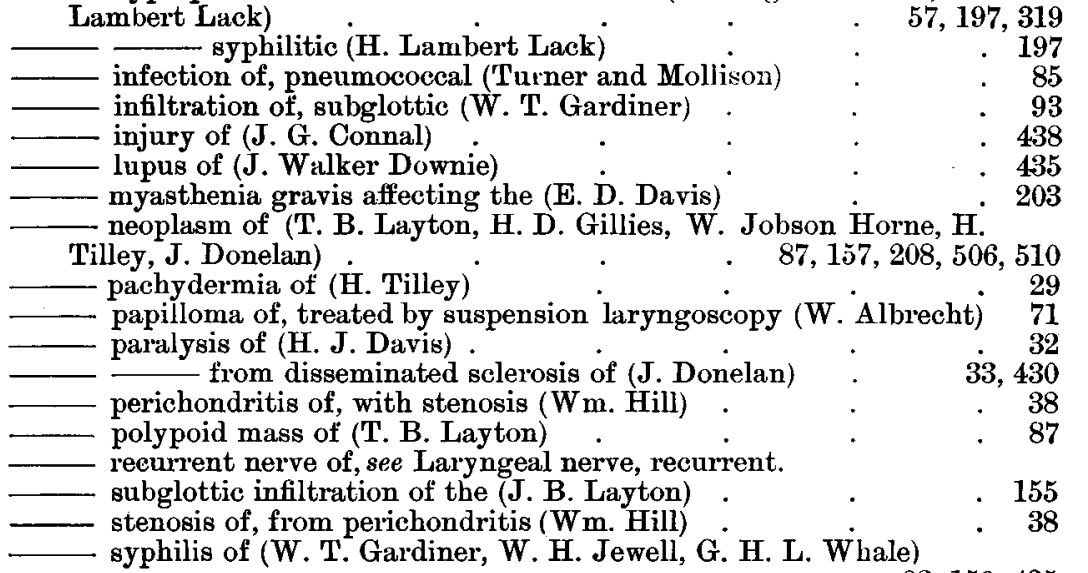

\begin{tabular}{lrr}
\hline & $93,159,425$ \\
\hline tobacco, effect of, on the (Colombel) & $\cdot$ & 107 \\
ventricular band of, hyperplasia of (C. I. Graham) & $\cdot$ & $\cdot 429$ \\
tuberculosis of (R. Levy). & $\cdot$ & $\cdot 50$ \\
\hline artificial pneumothorax and (E. Winckler) & $\cdot$ & $\cdot 107$ \\
\hline combined with syphilis (Dan McKenzie) & $\cdot$ & $\cdot 202$ \\
\hline dysphagia from, treatment of (Réthi) & $\cdot$ & $\cdot 217$
\end{tabular} 
Larynx, tuberculosis of, sanatorium treatment of (Sir StClair Thomson) $\begin{array}{r}\text { PAGE } \\ 54: 2\end{array}$

L treatment of, history of (M. Menier) . $\quad . \quad 50$

$\begin{array}{llr}- \text { ulceration, slight, painful (Dundas Grant) } & \cdot & 90 \\ \text { with thyroid perichondritis (G. Potts) } & \cdot & \cdot 156\end{array}$

Le Affezioni dell'Orecchio nell'Adenoidismo, by Dott. R. Vitto-Massei

(review, Sir StClair Thomson)

Leontiasis ossea

Leukæmia, lymphatic, tonsils from (H. J. Davis)

Lip, lower, bilateral fistulæe of (L. M. Kahn) primary syphilis of (H. J. Davis)

Little's area or locus Kiesselbachii (Dan McKenzie)

Lungs, emphysema of, causing scabbard-trachea (Kahler)

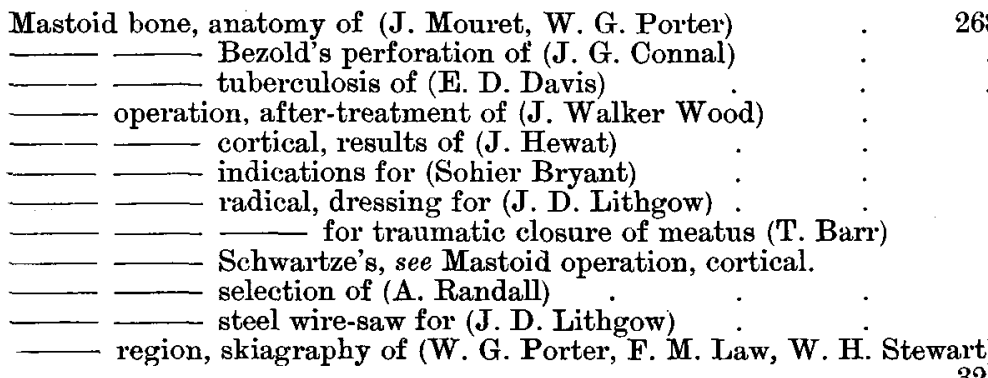

Mastoiditis, without middle-ear suppuration (Dan McKenzie) . $\quad 140$

Maxilla, expansion of, by spring pressure (J. Adam) . $\quad . \quad 474$ inferior, deformity of (H. J. Davis) $\quad$. $\quad . \quad 89$

\begin{tabular}{lllr}
- superior, osteoma of (Delman Ritehie) & $\cdot$ & $\cdot$ & $\cdot$ \\
\hline
\end{tabular}

Meatus, auditory, external atresia of, congenital (L. Lewin) $\quad . \quad 166$

- imperforate (H. J. Davis) . $\quad . \quad$. 315

Meckel's ganglion, intra-nasal access to (E. M. Holmes) $\quad . \quad$. $\quad$. 43

Membrana tympani, anthracosis of (J. E. Connal) . $\quad . \quad . \quad 438$

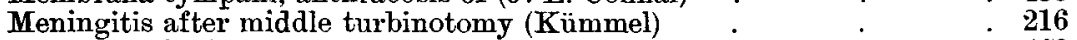
otitic, from abscess in petrous bone (G. Wilkinson) . $\quad . \quad 409$

- - Haynes' operation for (E. W. Day, E. D. Dench) $\quad 100,222$

-_ serous (J. G. Connal) . . . . $\quad 439$

Logan Translabyrinthine drainage, recovery (Sydney Scott, A.

$\overline{2}$ without rupture of the tympanic membrane (J. S. Fraser) 284

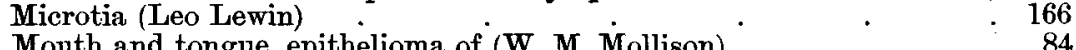

Mouth and tongue, epithelioma of (W. M. Mollison) . $\quad 84$

- aphthæ of, chronic recurring (Brown Kelly and W. Whitelaw) . 472

$\begin{array}{llll}\text { Mucosus streptococcus and otitis (E. Storath) } & \cdot & \cdot & \cdot \\ \text { Myasthenia gravis and the larynx (E. D. Davis) } & . & \cdot & .\end{array}$

Nasal reflex neuroses (O. Levinstein) ․ . . . . $\quad$. 49

Naso-pharyngoscope (J. Walker Wood) $\quad . \quad 16$

Naso-pharynx, adhesions in (H. L. Whale) $\quad$. $\quad . \quad 159$

fibroma of (W. N. Robertson) $\quad . \quad$. $\quad 47$

malignant tumours of (Kelsey and Brown) . $\quad . \quad+542$

- sarcoma of, treated by radium emanation (H. Tilley, A. J.

Martineau, Somerville Hastings) $\quad . \quad$ 150, 151 cicatricial web of (J. H. Connolly) : $\quad . \quad . \quad 37$

Neo-salvarsan, results from (E. Schlesinger) $\quad \cdot \quad \cdot \quad \cdot \quad \cdot \quad \cdot \quad 79$

Neuralgia, alcoholic treatment of, by nasal route (E. M. Holmes) : 43

Nose, alar cartilages of, collapse of (O. Paget) ․ . . . 385

bleeding polypus of (W. T. Gardiner) $\quad . \quad$. $\quad . \quad$. $\quad$ 94 


\section{Index.}

Nose, cancer of, (W. Stuart-Low) • . . . . . $\quad$ PAGR

development of (J. M. Ingersoll)

— diseases of, orbito-ocular complications of (Baumgarten) $\quad . \quad 49$

external, deformities of, treatment, see also Rhinoplasty.

- (Marshall) . . . . 54

hæmorrhage from thrombokinase in (de Roaldes and Lynch) . $\quad 274$

lupus of (G. H. L. Whale) . . . . . 426

$-\frac{1}{-}$ influence of pregnancy on (E. A. Peters) $\quad . \quad 509$

- lymphangitis of, from antrum suppuration (H. J. Davis) . 503

multiple telangiectasis affecting (Logan Turner) . $\quad .320$

neoplasms of, inoperable, treatment of, by diathermy (W. D.

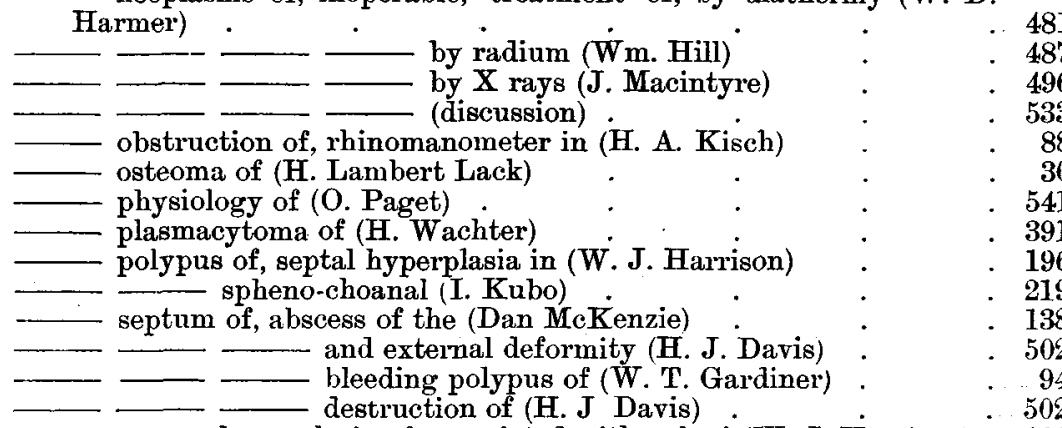

481

487

496

533

30

541

391

196

219

138

502

502

196

—— perforation of (Douglas Harmer) \begin{tabular}{r}
90 \\
\hline treatment of (W. J. Harrison, L. W. Simpson) \\
74,598
\end{tabular}

- posterior part, deflection of (N. Patterson) $\quad . \quad 207$

\begin{tabular}{rrr} 
resection of, anæsthesia for (A. Schulz) & 48 \\
\hline bi-submucous (J. v. d. H. Leonhard) & $\cdot$ & 419
\end{tabular} $\longrightarrow-$ in childhood (Heermann)

tubercle of, reflex neuroses from (O. Levinstein) $\quad 87,156$

tuberculosis of (A. Brown Kelly) . $\quad . \quad 4 \quad . \quad 471$

Nystagmus (Sydney Scott and discussion) : . $\quad . \quad . \quad . \quad 459$

labyrinthine, cortical centre for (J. G. Jenkins) ․ $\quad$. $\quad 23$

Oculo-motor paralysis of otitic origin (F. H. Westmacott) . 449

(Esophagoscopy (E. Killian, C. Jackson and discussion) $\quad . \quad 323,372$

for foreign bodies, mortality of (O. Jackson) . $\quad . \quad .373$

injuries resulting from (Amersbach) $\quad . \quad \cdots \quad . \quad 446$

Esophagus, cancer of, early symptomatology of (H. H. Janeway) . 447

- \begin{tabular}{ll}
4 \\
\hline
\end{tabular}

denture in, for eighteen years (D. Braden $\mathrm{Kyle}$ ) . $\quad . \quad 45$

$\begin{array}{ll}\text { foreign body in (D. R. Paterson, J. Guthrie). } & 276 \\ & \text { for two and a half years (Sir StClair Thomson) }\end{array}$ for eight years (W. G. Porter) $\quad$. $\quad 148,158$

of baby aged two (H. J. Davis) $\quad . \quad 89$

upper end of, cancer of see Pharynx, lower, cancer of. foreign bodies in, removal of (R. H. Johnston) . 332

Orbital cellulitis from nasal sinus disease (H. A. Kisch) . . 428

Orbito-ocnlar complications of ear disease (F. H. Westmacott) $\quad .449$

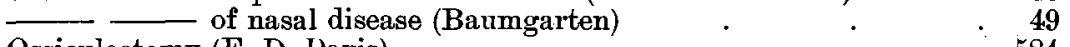

Ossiculectomy (E. D. Davis) • • . . 584

Osteomyelitis, diffuse cranial, of frontal bone (Eckstein) $\quad \vdots \quad \div \quad 275$ \begin{tabular}{lr}
\hline of sphenoid bone after adenoid (W. G. Porter) & 96 \\
328
\end{tabular}

Othæmatoma, see Auricle, hæmatoma of.

Otitis, see Ear. 
Otosclerosis, (A. Denker, J. S. Fraser, and Gideon Walker) clinical aspect of (J. S. Fraser and Gideon Walker) pathology of (G. J. Jenkins) treatment of (G. J. Jenkins)

52,211 PAGF 513 317,587

Ozæna, see Rhinitis, atrophic.

Palate, cancer (?) of (W. M. Mollison) endothelioma of (Dan McKenzie) epithelioma of (N. Paterson) hyperplasia of, congenital syphilitic (H. Lambert Lack)

lupus of (W. H. Kelson, J. Walker Downie)

33, 435

myasthenia gravis affecting the (E. D. Davis) _. 203

- necrosis of (H. J. Davis) . $\quad . \quad$. $\quad . \quad 502$

- paralysis of, following tonsil-adenoid operation (Logan Turner) 321

\begin{tabular}{llll} 
& & 32 \\
\hline
\end{tabular}

$\longrightarrow$ salivary adenoma of (T. Guthrie) $\quad \cdot \quad \cdot \quad$. $\quad 68,86$

ulcer of, perforating (W. H. Kelson) $\quad \cdot \quad . \quad 32$

Perez bacillus, vaccine of, for ozæna (Brown Kelly and J. F. Smith) 471 researches in ozæna (A. Brown Kelly) 255

Petrous bone, abscess of, causing paralysis of external rectus (G. Wilkinson)

Pharyngitis, pneumococcal (Turner and Mollison) streptococcus, epidemic (J. A. Copps) ulcerosa disseminata (O. Levinstein)

Pharyngo-laryngeal wall, cancer of (C. I. Graham)

Pharynx, angeioma of (Dan McKenzie) artery in, large (J. H. Conolly)

cancer of, operation (Lithgow and Ritchie, E. B. Wagget)

cicatricial diaphragm of (J. F. O'Malley) removal of (W. H. Kelson) . hyperplasia of mucous membrane of (A. Logan Turner)

lower, cancer of (H. Tilley, Logan Turner)

57,319

28,321

lupus of (W. H. Kelson)

. 474

- 33

. 160

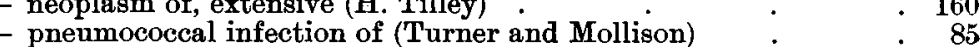

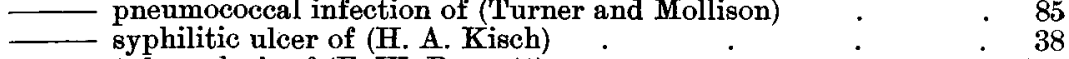

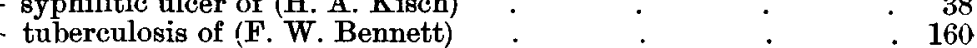

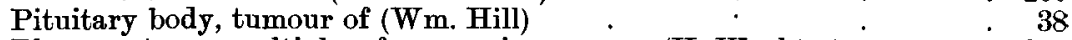

Plasmacytoma, multiple, of upper air-passages (H. Wachter) . $\quad . \quad 391$

Plaut-Vincent infection of ear (J. Adam) . . . . 538

Pneumococcal infection of pharynx and larynx (Turner and Mollison) $\quad . \quad 85$

$\begin{array}{ll}\text { Polycythæmia rubra with chronic rhinitis (E. A. Peters) . } & 157\end{array}$

Post-cricoid region, see Pharynx, lower.

Post-nasal region, see Naso-pharynx.

Pregnancy and lupus of nose (E. A. Peters) $\quad . \quad 509$

Principes d'Anacousie, by A. Zünd-Burquet (review, Dan McKenzie) : 111

Radiography, see Skiagraphy.

Radium, apparent cure of pharyngeal cancer by (J. Adam) . . 474 treatment of deafness (J. Walker Wood Max Halle).

-_ inoperable growths of nose and throat (Wm. Hill) $\quad .487$ emanation for naso-pharyngeal sarcoma (H. Tilley, A. J. Martineau, Somerville Hastings)

Rectus, external, paralysis of in ear disease (F. F. Muecke)

Recurrent nerve, see Laryngeal nerve, recurrent. 
Re-education of hearing, see Deafness, re-education treatment of.

Respiratory tract, upper, a peculiar form of hyperplasia of the mucous membrane of (A. Logan 'Turner) otogenic (S. Gatscher) space, foreign body in (E. D. Davis)

Rhinitis, atrophic (Johnathan Wright, F. P. Emerson)

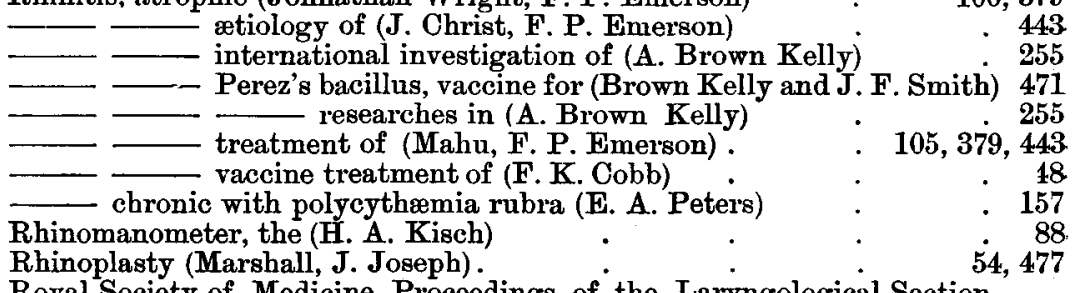

Royal Society of Medicine, Proceedings of the, Laryngological Section $28,79,147,197,500,589$

Sections Neurological, Ophthalmological and Otological Otological Section $22,75,140,312,580$

Salvarsan, adrenalin in treatment by 168 in lesions of nose and throat (C. R. C. Borden, E. Schlesinger) 278,279 Scabbard-Trachea, see Trachea.

Scottish Otological and Laryngological Society, Proceedings of the

Semicircular canals, ampullæ of, in birds (U.Pritchard) $161,211,319,435,466,538$.

$$
\text { function of, in cochlear disea }
$$

Semon Lecture, the, 1914 (Prof. G. Killian)

Septum, nasal, see Nose, septum of.

Sinus, antral, see Antrum, maxillary.

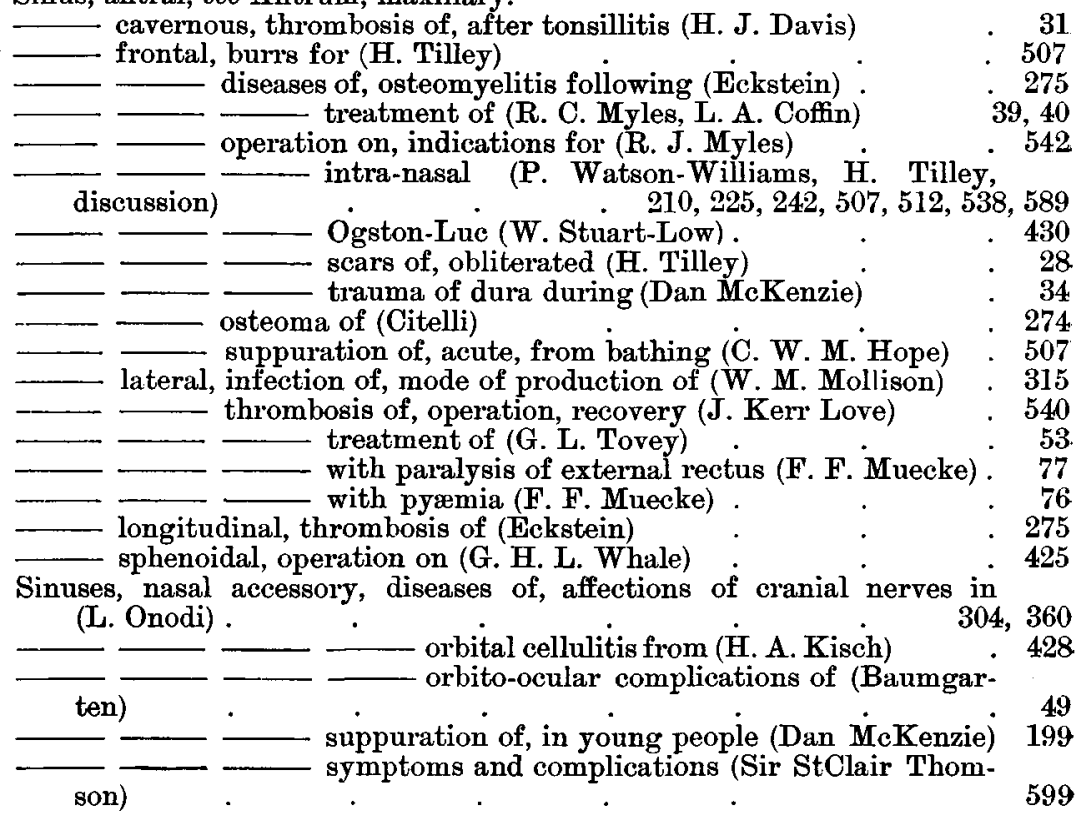


Sinuses, nasal accessory, The Catarrhal and Suppurative Diseases of the, by Ross Hall Skillern, M.D. (review, Dan McKenzie) . 391

Skiagraphy and per-oral endoseopy (C. Jackson) . . . 373

- of mastoid region (W. G. Porter, F. M. Law, W. H. Stewart) 323, 387

Skull, fractures of base of, involving temporal bone (Kirchner, E. D.

Davis)

Snoring, laryngeal (W. F. Chappeli)

Sound-waves, photographs of (R. Lake)

446,581

Spheno-palatine ganglion, see Meckel's ganglion.

Sphenoid bone, osteomyelitis of, after adenoid operation (Jolly) • 328

Sphenoidal sinus, see Sinus, sphenoidal.

Stomatitis ulcerosa disseminata (O. Levinstein)

Suspension laryngoscopy (W. Albrecht, E. D. Davis, E. Mayer, G. Killian, W. Freudenthal)

Temporal bone, anatomy of (J. Mouret, H. Frey) ․ . $\quad 268,386$

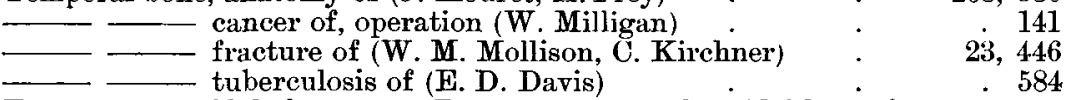

Temporo-spenoidal abscess, see Brain, temporo-sphenoidal lobe of.

The Diseases of the Nose, Throat and Ear of Children in Daily Practice, by Prof. Dr. F. Goppert (review, A. R. Tweedie)

Throat, neoplasms of, inoperable, treatment of, by diathermy (W. D.

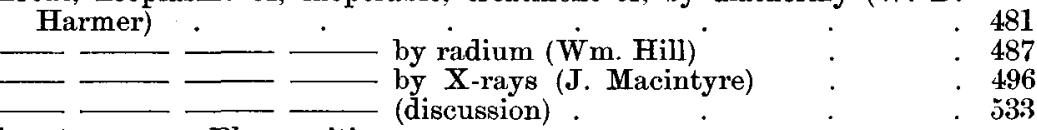

Throat, sore, see Pharyngitis.

Thrombokinase for hæmorrhage (de Roaldes and Lynch) . . . 274

Thymus gland, hypertrophy of, thymectomy (A. Jouty) . . 390

Thyro-glossal cyst (J. L. Howie) - . . . 471

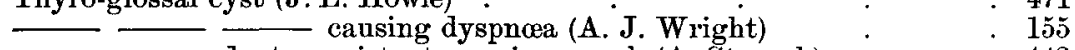

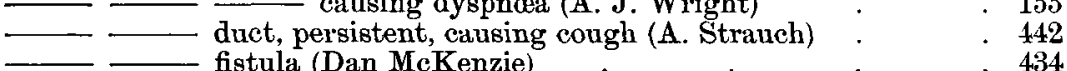

Thyroid gland, see also Goitre. fistula (Dan MeKenzie)

diseases of, and throat and nose infection (Beebe) . 541

Thyrotomy (F. R. Packard) . . . . . . . 166

Tinnitus, persistent, section of auditory nerve for (C. H. Frazier) : 222

Treatment of (W. C. Braislin) _ $\quad . \quad$. $\quad .479$

Tobacco, effect of, on larynx (Colombel) $\quad \cdot \quad \cdot \quad \cdot \quad \cdot \quad \cdot \quad \cdot \quad 107$

Tongue, leukoplakia of (J. Walker Downie). $\quad$. $\quad$. $\quad$. 435

- operations on (F. Kuhn) . . . . $\quad 273$

Tonsil, faucial, calculus of (J. Walker Downie) $\quad: \quad: \quad \cdot 322$

- cancer of, operations for (F. Kuhn) : $\quad: \quad: 273$

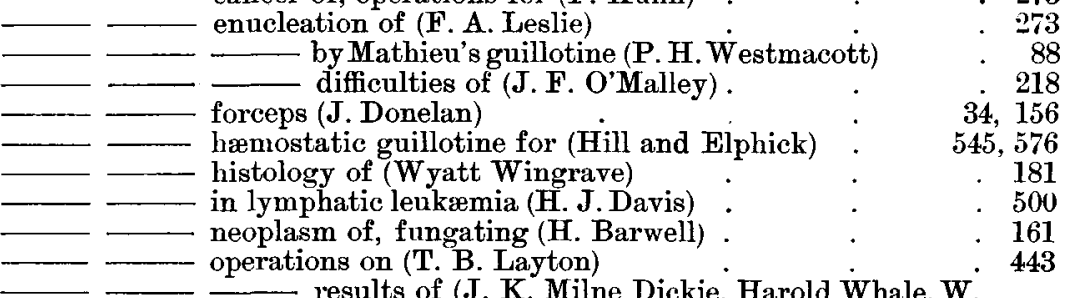

Wilson, A. Logan Turner) $\quad 184,218,321,329$

- passage of bacteria through (G. B. Wood)

Henke) physiology of (L. M. Freedman, J. Gordon Wilson, F.

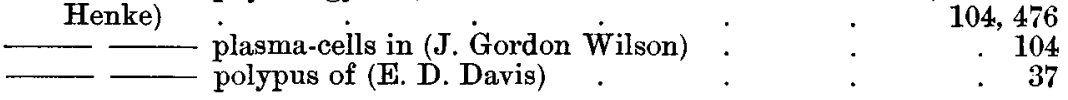


Tonsil, faucial, pulmonary tuberculosis and the (E. Fletcher Ingalls) PAGE -1 relation of cervical tuberculous adenitis to (A. Philps

$\frac{\text { Mitchell) }}{\text { Tonsillectomy, see Tonsil, faucial, enucleation of. }} \cdot \cdot \cdot \quad \cdot \quad \cdot 32$

Tonsillitis, acute, salicylate of iron for . . . . . . 56

- follicular, cavernous sinus thrombosis after (H. J. Davis) . 31

Tonsillotomy, death after (Dan McKenzie) . $\quad$. 35

Trachea, displacement of, from thoracic disease (K. $\dot{M}$. Mentzel) $\quad: \quad 385$

the seabbard-, from pulmonary emphysema (Kahler) . : 7

Tracheotomy, transverse incision in (O. Franck) . : $\quad .444$

Tricophyton granuloma of auricle (Hunter Tod) $\quad$ : $\quad$. $\quad$. 26

Turbinal body, see also Nose. \begin{tabular}{lrr}
\hline & $\cdot$ & 384 \\
\hline cauterisation of, effects of (Pierre Bonnier) & $\cdot$ & 92 \\
hypertrophy of, treatment (J. D. Lithgow) & $\cdot$ & 48 \\
bone, middle, removal of (W. S. Renner) & $\cdot$ & $\mathbf{2 1 6}$
\end{tabular}

Tympanic cavity, see Ear, middle.

Urotropin for meningitis (A. Logan Turner) . . . . 321

Uvula, cavernous angeioma of (Dan McKenzie) $\quad \cdot \quad$. $\quad . \quad 202$

Vaccine treatment of inflammations of upper air-tract (Douglas Harmer) 389

Vertigo, aural, labyrinthotomy for (R. Lake, W. H. Kelson) . 144, 318

Vestibulotomy, see Labyrinthotomy.

Voice, effect of atropin on (Cisler)

$\mathrm{X}$ rays, see also Skiagraphy.

\section{AUTHORS.}

ADAM (James), cancer of hypopharynx . . . . . 474

s), cancer of hypopharys

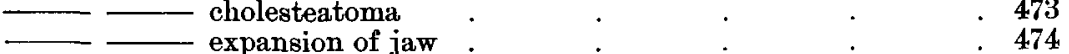

- Plaut-Vincent infection of ear . . . . 538

Alba NUS, diathermy . . 216

AMBERG (E.), middle-ear suppuration : $\quad$ : $\quad$. $\quad$. 278

AMERsbaCH (K.), osophagoscopy. $\quad . \quad$. $\quad . \quad .446$

BÁRÁNY (R.), deafness from meningitis . $\quad$. $\quad$. $\quad$. 2

BARR (Thomas), traumatic closure of meatus $\quad \therefore \quad \therefore \quad \therefore 36$

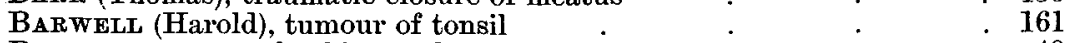

BADMGARTEN, nasal orbito.ocular disturbances : $\quad: \quad: \quad 49$

BECK (Oscar), syphilitic deafness . $\quad . \quad: \quad . \quad .388$

Bennet (F. W.), tuberculosis of pharynx : $\quad: \quad: \quad: 160$

- and McKenzie (Dan), labyrinthitis $:{ }^{\circ}$. 141

BEERE (S. P.), hyperthyroidism and the nose and throat $\quad . \quad$. 541

BIRKETT (H. S.) and Rogers, abstracts

$50,54,104,105,164,222,275,278,511,541,598,599$

BonNIER (Pierre), hæmorrhoids and bulbar toxicity .

Boot (G. W.), caisson workers' deafness . $\quad: 600$

Booth (J. Mackenzie), re-education of hearing $\quad: \quad \cdot \quad \cdot \quad: 466$

Borden (C. R. C.), salvarsan $\quad: \quad: \quad 278$

Bowen (H. M.), dangers of antral puncture $\quad: \quad \cdot \quad \cdot \quad 219$

BoYd (W.) and HoPwOOD (J. S.), cerebral auditory centre : . 479 
Brady (A. J.),[abstracts

BrAISLIN (W. C.), treatment of tinnitus

$47,384,385,386,541$

BRYANT (W. Sohier), aids to hearing mastoid hearing .

CAPPS (Joseph A.), epidemic sore throat

CavanaUgh (John A.), topography of the tympanum

ChapPell (Walter F.), broncholith laryngeal diagnosis

Christ (J.), ozæna

Cisler, atropin poisoning

CiTELLI, frontal sinus osteoma

CoBB (F. K.), atrophic rhinitis

CoFrin (Lewis A.), frontal sinus disease

CoLOMBEL, tobacco laryngitis

CoNNAL (J. Galbraith), anthracosis of tympanic membrane

479

Conolcy (J. H.), deformities of external ear large pharyngeal artery nasopharyngeal wet

Coolidge (A.), hay-fever

DAVIS (E. D.), abductor paresis

foreign body in retro-pharyngeal space

fracture of temporal bone.

myasthenia gravis

ossiculectomy

polyp of tonsil

suspension laryngoscopy .

- tuberculosis of mastoid

DAvis (H. J.), abnormal pharyngeal artery

cancer of ethmoid
cavernous sinus tbrombosis

_- deformity of lower jaw

_- destruction of nasal septum

— fixation of cord .

__ foreign body in cesophagus

- herpes zoster of auricle

- imperforate meatus

- laryngeal fibroma

___ lymphangitis of nose and cheeks lymphatic leukæmia

—_ necrosis of palate

primary syphilis of lip

DAY (Ewing W.), Haynes operation

DE ROALDES (A. W.) and LYNCH (C.), thrombokinase

De Santi (P. R. W.) cancer of epiglottis

DeMPSEY (Patrick), pharyngeal diverticulum

DENCH (E. D.), Haynes operation for meningitis

DENKER (Alfred), otosclerosis

DiCKIE (J. K. Milne), laryngeal stridor prolonged hoarseness tonsil operations

DIGBY (Kenelin H.), otosclerosis

DONELAN (J.), disseminated sclerosis

205,432

. 206

. 581

. 203

. 584

. 37

. 206

582,584

. 502

$\therefore 504$

30

89

502

89

89

314

315

88

503

500

502

31

502

500

100

274

90

148

222

52

99

98

184

20

33,430 instruments for septal resection 
Donklan (J.), neoplasm of vocal cord tonsil forceps

DownIE (J. Walker), calculus of tonsil

- leukoplakia of mouth

- Iupus of palate, etc. recurrent nerve paralysis:

Eckstein, osteomyelitis of frontal bone

ELPHICK (G. J. F.), Hild (Wm.), and, tonsillectomy.

Emerson (Francis P.), ozæna

Fowler (E. P.), sequestrum of semicircular canals .

Fox (H. Clayton), abstracts

. 220

FraNk (O.), tracheotomy

FrASER (J.S.), abstracts $48,49,50,107,164,166,273,275,279,329,443,444$

FRASER demonstration of diseases of ear $164,166,273,275,279,329,443,444$

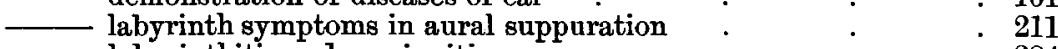

- laby rinthitis and meningitis

- _ serous labyrinthitis

- and WALKER (Gideon), otosclerosis

Frazier (C. H.), section of auditory nerve.

FreEdMaN (L. M.), function of tonsil

Freudenthal (Wolff), general anæsthesia.

- suspension laryngoscopy

Frey (Hugo), anatomy of temporal bone

GARDiner (W. T.), bleeding polypus of septum . . . . $\quad .94$

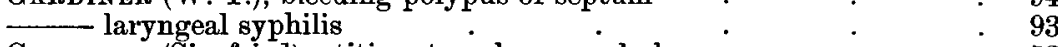

GATSCHER (Siegfried), otitic retro-pharyngeal abscess $\quad \cdot \quad \cdot \quad 53$

GILLIES (H. D.), tumour of vocal cord . $\quad . \quad: \quad 157$

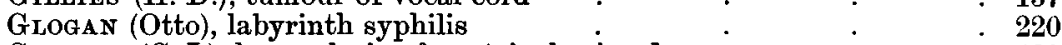

GrahaM (C. I.), hyperplasia of ventricular band : $\quad: \quad: 429$

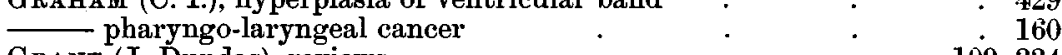

GRANT (J. Dundas), reviews $\quad . \quad$. $\quad$. $\quad$. $\quad 109,334$

- tuberculous ulcer of larynx $\quad \cdot \quad \cdot \quad \cdot \quad \cdot \quad \cdot 90$

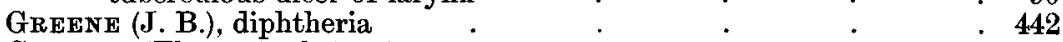

GUTHRIE (Thomas), abstracts $48,49,219,328,331,385,386,391,446,447,476,479$ foreign bodies in œsophagus . $\quad . \quad . \quad .158$

\begin{tabular}{lllll} 
- & $\cdot$ & $\cdot$ & 68,86 \\
\hline translation adenoma of palate & $\cdot$ & $\cdot$ & $\cdot$ & 68
\end{tabular}

HARMER (Douglas), cyst of pharyngeal wall . . . . . 434 diathermy for growths of nose and throat $\quad \cdot \quad \cdot v^{-} \quad \cdot 481$ perforation of nasal septum $\quad . \quad 5 \quad . \quad 5 \quad . \quad 50$

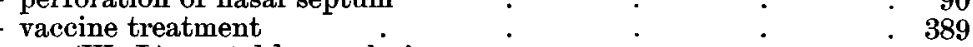

HARRISON (W. J.), septal hyperplasia $\quad: \quad \cdot \cdot \quad \cdot \quad \cdot 196$ septal perforations

HaSTINGS (Somerville), deafness, diagnosis:

- radium for naso-pharyngeal sarcoma

HeErmanN, septal resection in childhood .

HENKE (F.), function of tonsils

Heschl (Friedrich), obstructive deafness

HEWAT (J.), cortical mastoid operation statistical tables.

HILL (Leonard) and MuECKE (F. F.), colds in the head

HILL (W.), diverticulum of pharynx

perichronditis of larynx pituitary tumour radium for growths of nose and throat and ElPHICK (G. J. F.), tonsillectomy 
Holmes (E. M.), injection of Meckel's ganglion . . . PAGR

HoPE (C. W. M.), double abductor paralysis $\quad . \quad 431$

frontal sinusitis from bathing . . . . $\quad 507$

HoRGAN (J. B.), abstracts ․ $\quad 273,386,442,444,446,477$

Hor Ne (W. Jobson), gun-deafness $\quad . \quad$. $\quad . \quad 600$

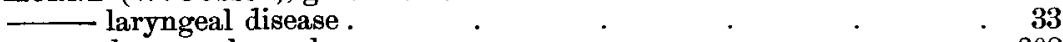

laryngeal neoplasm

HowarTh (W. G.), cancer of palate tumour of superior maxilla

Howre (J.L ), thyroglossal eyst .

Hutchrson (A. J.), abstract

IMHOFER (R.), abscess of larynx .

INGALLS (E. Fletcher), tuberculosis and the tonsils

INGERSOLL (J. M.), development of the face

Jackson (Chevalier), endoscopy .

JAEHNE (A.), herpes zoster oticus

JANEWAY (H. H.), cancer of œesophagus

JENKINS (G. J.), hæmatoma auris . histology of otosclerosis

- labyrinthitis

treatment of otosclerosis :

and Stebring (G. F.), cancer of ear

JEWELL (W. H.), aphonia

JoHnston (Richard H.), foreign bodies in œosophagus

JoLLY (R. H. H.), osteomyelitis after adenoid operation

JosePH (J.), rhinoplasty .

JouTy (Antoine), thymectomy

KaBATSCHNIK (M.), new hearing test

KAHLER (Prof.), scabbard-trachea

KАHN (L. M.), fistula of lower lip .

KATZENSTEIN, direct laryngoscopy

KELLY (A. Brown), endothelioma of antrum

exploratory puncture of antrum

_ ozæna

tuberculosis of nose

- and SмiтH (J. F.), vaccine treatment ozæna

and WHITELAW (William), aphthæ of mouth

Ketsey (A. L.) and BRown (J. M.), cancer of naso-pharynx

KELsoN (W. H), labyrinthotomy for vertigo

- lupus of pharyn

new Eustachian bougie
perforating palatal ulcer
recurrent nerve paralysis .

recurrent nerve paralysis.
removal of pharyngeal pouch

KILlian (G.), dangers of puncture of antrum endoscopic methods

—_ laryngeal cancer : recurrent paralysis in heart disease.

- suspension laryngoscopy .

KIRCHNGR (Carl), fractures of base of skull

KIsch (H. A.), orbital cellulitis rhinomanometer.

- syphilis of pharynx

KowleR, retropharyngeal abscess

KREIDL, acoustic tracts .

KR ÜGER, othæmatoma

Kणво, spheno-choanal polypus

KUHN (Franz), surgery of mouth .

KÜMMEL, meningitis from middle turbinotomy 
KYLE (D. Braden), denture in œsophagus

PAGE

45

LACK (H. Lambert), osteoma of nose presidential address syphilitic thickening of palate

LAKE (R.), aural vertigo operation re-education treatment of deafness sound wave phøtographs.

LAVRAND (H.), phonatory ear massage

LAw (Fred M.), skiagraphy of mastoid

LAYTON (T. B.), bilateral abductor paralysis fixed crico-arytænoid joint laryngeal disease laryngeal tumour subglottic swelling tonsil and adenoid operations

LEIDLER (R.), labyrinthotomy

LEONHARD (J. van der Hoeven), bi-submucous resection

LEsLif (F. A.), tonsil enucleation .

Levinstein (Oswald), nasal antrostomy nasal reflex neuroses stomatitis ulcerosa disseminata

LEVY (Robert), laryngeal tuberculosis

Lewin (Leo), atresia of auditory meatus

LrTHGOW (J. D.), abstracts ethyl chloride mastoid dressing

wire saw for mastoid operation and Peel Ritchie, cancer of pharynx turbinal hypertrophy

Love (J. Kerr), lateral sinus thrombosis sudden non-syphilitic deafness in children temporo-sphenoidal abscess

Lovelu (A. G. Haynes), hay-fever

LUC (H.), operation on ethmoid

Macrntyre (J.), X-rays for inoperable cancer

McKenzie (Dan), angeioma of uvula endothelioma of ethmoid of palate

laryngeal tuberculosis with syphilis . mastoiditis

maxillary antroscope

nasal septal abscess

nasal sinus suppuration

nerve deafness and anæmia

operative trauma of dura.

tonsillotomy, death

and BenNeTT (F. W.), labyrinthitis

MacLAT (Neil), cholesteatoma

MacMaHon (Cortlandt), functional aphonia

МанU (G.), ozæna

ManN (Max), cerebellar abscess

MARSHALL, external nasal deformities

MaRTineaU (A. J.), radium for naso-pharyngeal sarcoma MARX, eventratio diaphragmatica.

MAYER (Emil), cancer of epiglottis reports.

Menier (Marius), laryngeal tuberculosis Mentzex (K. M.), displacement of larynx Milligan (Sir W.), cancer of ear .
30

532

197

144

318, 543

146

109

387

154

86

87

87

155

443

220

419

273

329

49

164

50

166

92

91

323
$107,108,109,384,444$ 
Milluigan (Sir W.), cerebellar abscess MitcheLL (A. Philp), tonsils and tuberculosis MoLlison (W. M.), cerebello-pontine lesion epithelioma of mouth injury to ear

lateral sinus thrombosis palatal cancer (?)

- and TURNER (Phillip), pneumococcal pharyngitis

Mortimer (J. D.), review

ModRet, (J.), anatomy of mastoid

MUECKE (F. F.), auditory re-education

lateral sinus thrombosis

and HiLL (Leonard), colds in the head

MYGIND (S. H.), rheumatism of crico-arytænoid joint

MYLes (R. C.), frontal sinus disease

O'MaLley (J. F.), pharyngeal diaphragm .

ONODI (L.), rhinogenic and and otogenic lesions of cranial nerves

Packard (F. R.), thyrotomy

Paget (Owen), adenoids

$$
\text { nasal obstuction . }
$$
physiology of nose

Panconcellia-Calzia, the autophonoscope

Paterson (D. R.), endoscopy foreign body in bronchus .

intra-nasal treatment of lachrymal disease translation

Patterson (Norman), epithelioma of soft palate

$\underline{1}$ posterior septal deflection

Pern (S.), congenital goitre

Peters (E. A.), abductor paresis . laryngeal infiltration cesophageal cancer polycythæmia rubra pregnancy and lupus of nose

Phillips (Wendell C.), otorrhoea in infancy

Polý́k (L.), dacrjocystostomy

Porter (W. G.), cesophageal foreign body osteomyelitis of frontal bone skiagraphy of mastoid region temporo-sphenoidal abscess

Potrs (G.), laryngeal tuberculosis

PritchaRd (Ưrban), anatomy of semicircular canals

RAE (John B.), gunshot wound of ear

RANDALL, mastoid operations

RAOULT, auditory re-education

REH and MÉRoz, otitis media

RENNER (W. Scott), removal of middle turbinal

RENSHAW (J. A. Knowles) abstracts

RETHI, laryngeal tuberculosis

RICHARDSON (C. W.), vaso-motor disturbances

RITchIE (Delman), osteoma of superior maxilla

ROBERT-LeRoUX, laryngoscopy

ROBERTSON (W. N.), naso-pharyngeal fibroma

RoLLeston (J. D.), Vincent's angina

Rutrin (Erich), labyrinthitis 
SCHLESINGER (E.), neo-salvarsan

Schwarz (Adolf), earache . . . . . 445

ScotT (Sydney), cancer of ear $\quad . \quad \therefore 143$

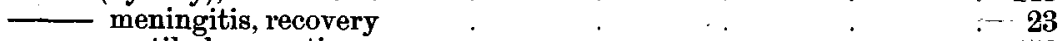

- vestibular reactions $. \quad . \quad \% 459$

SCRIPTURE (E. W.), speech without a larynx . $\quad \therefore 275$

Simpson (W. Likely), septal perforations . . . . 598

SMITH (J. F. A.), and BRowN KkLLY, vaccine treatment of ozæna : 471

SMiTh (T.), hay-fever . . . $\quad 50$

SoBERNHEIM and CARO, recurrent paralysis $\quad: \quad$ : $\quad 219$

Stebbing (G. F.) and Jenkins (G. J.), cancer of ear $\quad . \quad \cdot 27$

STEWART (Wm. H.), skiagraphy of mastoid $\quad \therefore 387$

Storath (E.), capsulated coccus otitis . . . . . . . $\quad .276$

Stradch (August), thyro-glossal duet $\quad . \quad$. $\quad$. $\quad .442$

StUarT-Low (W.), epithelioma of antrum . $\quad$. $\quad$. 506

- frontal sinus operation.$\quad$. $\quad . \quad 430$

STURM (F. P.), new theory of hearing $\quad, . .193$

SYme (W. S.), reports . $\quad . \quad 91,161,211,319,435,466,538$

Tromson (Sir StClair), foreign body in oesophagus . . . 276

laryngeal tuberculosis

— review.

- sinusitis $\quad . \quad$. $\quad . \quad-599$

TILLEY (Herbert), foreign body in bronchus $\quad$. $\quad . \quad 80$

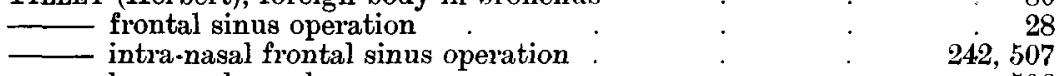

_ laryngeal neoplasm . . . . . . . 506

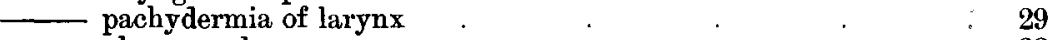

- pharyngeal cancer . . . . 28

- C tumour . . . . . . . 160

_ radium for naso-pharyngeal sarcoma $\quad . \quad . \quad 150$

TOD (Hunter), trichophyton granuloma of auricle $\quad \cdot \quad$. $\quad . \quad 26$

ToveY (G. L., jun.), lateral sinus thrombosis .

\begin{tabular}{l} 
ToRNER (A. Logan), cancer of cesophagus : $\quad: \quad 57,133,184,261,284$ \\
\hline
\end{tabular}

—_ meningitis, recovery . . . . . . 321

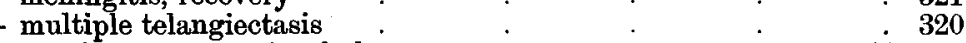

peculiar hyperplasia of pharynx $\quad . \quad 5 \quad$. $\quad . \quad 57,319$

- results of tonsil-adenoid operation . $\quad . \quad$. 321

- sarcoma of tonsil . . . . . . . 321

Torner (Phillip) and Mollison (W. M.), pneumococcal pharyngitis : 85

TwEEDIE (A. R.), abstracts $\quad 51,53,166,332,388,445,511,543$

review

translation

ULRICH (Henry L.), hay-fever . . . . 511

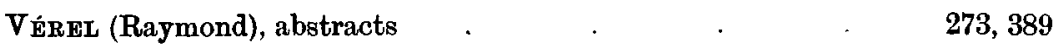

WACHTER (H.), plasmacytoma of nose . . . . 391

W AGGETT (E. B.), resection of pharynx and larynx . . . 424

WALKER (Gideon) and FRASER (J. S.), otosclerosis . 211, 513

WARNER (F.), muscular exercises after adenoid operation . . 329

WATSON-WILLIAMS (P.), cerebro-spinal rhinorrhoea . $\quad . \quad 82$

intra-nasal frontal sinus operation. $\quad 210,225,512,589$

nasal antrostomy

113,429 reviews.

WEST (C. E.), cerebellar abscess

WESTMACOTT (F. H.), submucous resection

$54,110,167$ tonsil enucleation 
Whale (G. H. L.), gummatous laryngitis . . . . ${ }_{425}^{\text {PaE }}$ lupus of nose

- naso-pharyngeal adhesions $\quad . \quad$. $\quad . \quad 159$

reports

report

sphenoidal sinus operation

- temporo-sphenoidal abscess

tonsil operations

532.576

. 425

. 580

. 218

Whitehouse (H.) and Connal (J. G.), cerebellar abscess : : 441

WHITELAW (William) and KELLY (A. Brown), aphthæ of mouth . 472

WILKINSON (Geo.), fixation of arytænoid . . . 426

foreign body in larynx

otitic paralysis of external rectus

WILson (J. Gordon), plasma cells in tonsil .

WINCKLER (Ernst), laryngeal tuberculosis .

Wingrave (Wyatt), histology of tonsil

Woop (Geo. B.), bacteriology of tonsil mastoid operation

Woon (J. Walker), radium for deafness treatment of Eustachian tube

Woody (Samuel S.), antitoxin in diphtheria

WRIGHT (Jonathan), atrophic rhinitis

WRIGHT (A. J.), abstracts thyro-glossal cyst

WYLIE (Andrew), chronic laryngitis

YEARSLEY (Macleod), abstracts $48,52,53,104,165,166,218,219,220,276$, $278,328,331,334,387,442,443,445,478,479,510,542,543,599,600$ prevention of deaf-mutism

reviews.

55,480 


\title{
HOSPITAL FOR \\ DISEASES OF THE THROAT,
}

GOLDEN SQUARE, LONDON, W.

\author{
HONORARY MEDICAL STAFF. \\ Consulting Surgeons $\left\{\begin{array}{l}\text { MR. MARK HOVELL. } \\ \text { DR. LAMBERT LACK. }\end{array}\right.$
}

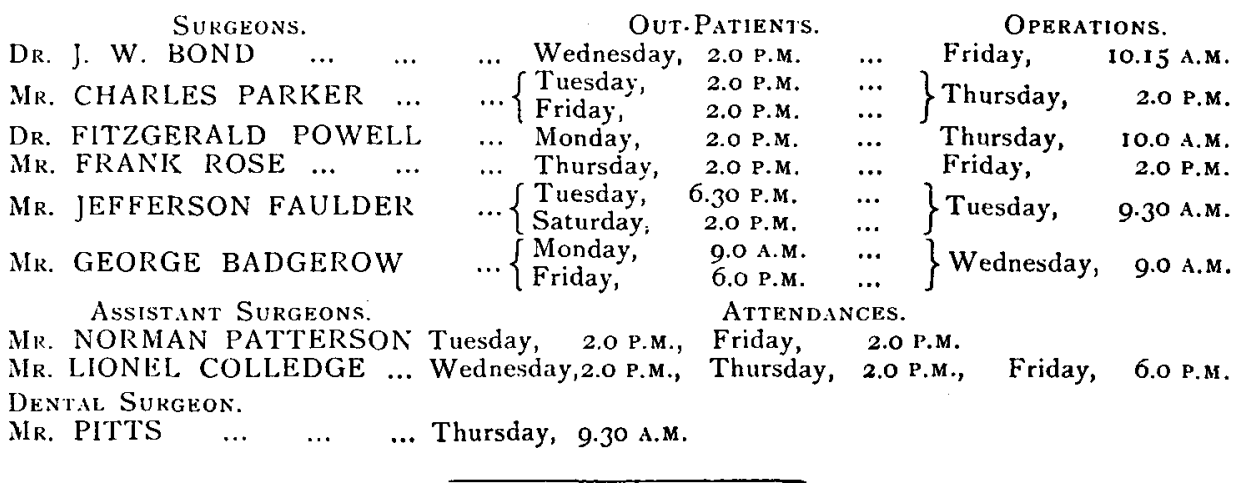

\section{CLINICAL INSTRUCTION.}

A Clinical Demonstration on the Diagnosis and Treatment of Selected Càses (Larynx, Nose, Ear) will be given each Monday at 5 p.m.

A Course in Surgical Anatomy and Physiology will be given each Thursday at 5 p.m. These Courses are free to Students of the Hospital. Others a fee of 2 guineas for each Course.

Practical Instruction in the Diagnosis and Treatment is given daily in the Out-patient Department from 2 to 5 p.m., on Tuesdays and Fridays from $6.3 \circ \mathrm{p} . \mathrm{m}$. to 9 p.m., and Mondays at 9.30 a.m.

Major Operations are performed at 10 a.m. on Tuesday, Wednesday, Thursday, Friday, and Saturday, and Fridays at 2 p.m.

Minor Operations daily (Mondays excepted) at $9.30 \mathrm{a} . \mathrm{m}$.

Operative Surgery Classes can be formed at any time on application.

Practice in Direct Laryngoscopy, Tracheoscopy, Bronchoscopy, and Esophagoscopy will be given to Students, to enable them to become famiiiar with the use and manipulation of the instruments.

Practitioners and Medical Students are admitted to the Practice of the Hospital at a fee of five guineas for three months, eight guineas for six months, or ten guineas for a Perpetual Studentship. Each course may commence at any date. Special terms to men in actual practice who can only attend the hospital once or twice a week.

The Hospital contains 60 beds for In-patients. There is also an Out-patient attendance of nearly 50,000 yeariy.

Gentlemen may enter to the practice of The Throat Hospital at any time, and on certain conditions eligib!e for appointment as Clinical Assistants, whose duty it is to Assist the Member of the Staff to whom they are appointed.

GEORGE W. BADGEROW, F.R.C.S., Hon. Med. Sec. 


\section{WRIGHT, PUBLISHERS, BRISTOL.}

Demy 8vo, with 77 Illustrations, 44 of which are in Colours. 7 i6 net.

\section{Diseases of the \\ THROAT,
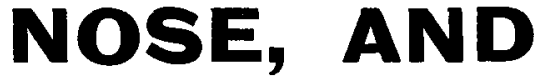 \\ EAR}

For Practitioners and Students.

By W. G. PORTER, M.B., B.Sc., F.R.C.S.Ed.,

Surgeon to the Eye, Ear, and Throat Infirmary, Estinburgh; Surgeon, Ear and Throat D purtment, Royal Hospilul for Sich Children, Eainburgh; Aurist to the Finburgh Royal Institution for the Elucation of the Deaf ant Dumb.

"The author's main object has been to provide the practitioner and serious student with a single volume of moderate size, embracing sufficient information on the diseases of the throat, nose, and ear, to be of value in practice. We may say at once that he has attained his object."-B,itish Medicul fournal.

"Fminently suited to the purpose for which it is designed." - Journal of Laryngulngy.

"The several diseases are concisely dealt with. . . The book as a whole refects sound teaching, and recent literature has evidently been laid under contribution. "It is well printed and well illustrated."-Lancet.

"The work is eminently suited to the purpose for which it has been designed. . a large amount of well. digested and accurate information has been packed into a surprisingly small compass. Special attention has been given to diagnosis, and to such treatment as can be carried out snccessfully by one who is not a specialist. . We congratulate ir. Porter upon producing a rery excellent small manual." - Practitioncr.

Originally published in 1912, the first Large Edition was exhausted in Six Months.

The second Impression was quickly sold out, and the Third Issue is now ready.

Demy 8vo. 1030 pages. With 16 Coloured Plates and over 200 lllustrations in the Text. Bevelled Boards, Burnished Top. 30/- net.

\section{AN INDEX OF DIFFERENTIAL DIAGNOSIS OF MAIN SYMPTOMS By Many Writers.}

Edited by HERBERT FRENCH, M.A., M.D.0xon., F.R.C.P.Lond.

"May be said to represent the last word as to limits of diagnostic power. . . illustrations are of a uniformly high merit, and aid materially. . . of Dr. French's work, both as editor and contributor, we cannot speak too highly . . This remarkable index."-British Medical Fournal.

"All that it is possible to learn of medicine in its various branches outside the wards of a hospital will be found in this book."-Practitioner.

6th Edition. $13^{\text {th }}$ Thousand. Completely Revised, with additional Articles and lllustrations. Demy 8vo. I056 pages. Bevellid Boards, Burnished Tops. 21/-net.

\section{AN INDEX OF TREATMENT}

\section{By 83 Representative Contributors.}

Edited by ROBERT HUTCHISON, M.D., F.R.C.P., Physician to the London Hospital.

A Complete Guide to Treatment in a Form Convenient for Reference.

"The editors and publishers may be congratulated on the production of a work of reference which we can cordially recommend to all busy practitioners." - Bri.i.h Melical Fon mal.

"The book is of special use to the general practitioner, who will tind in it many valuable suggestions for the manayement of disease."-Lancet.

"Handy, accurate. . easy of re erence. . We congratulate editors and contributors uron having added to medical literature a useful and comprehensive work." -Melical Press and Circulur.

Now Ready. Fourth Edition. Fully Revised. Crown 8vo. 9/6 net. With Diagrams of Surface Markings.

\section{SYNOPSIS OF SURGERY}

For Students and Practitioners.

By ERNEST W. HEY GROYES, M.S., M.D., B.Sc.Lond., F.R.C.S.Eng.

". . appears to contain all that is necessary in a synopsis, and... is not too condensed. . . may be legitimately employed for revising knowledge." - Lancet.

"The additions necessary to keep it quite up to date have been freely made.. . . Among the best of its kind, and the author is to be congratulated on its readableness, its lucidity, and its fulness-notable qualities." british Medical Jounal.

Bristol: JOHN WRIGHT \& SONS, Limited.

London: SIMPKIN, MARSHALL, HAMILTON, KENT \& Co., Ltd. 


\section{GENTRAL LONDON THROAT AND EAR HOSPITAL GRAY'S INN ROAD (Near King's Cross Stations).}

The work carried on at this Hospital comprises:

1. The Daily Out-Patient Olinic.

'The Medical Officers attend as follows :

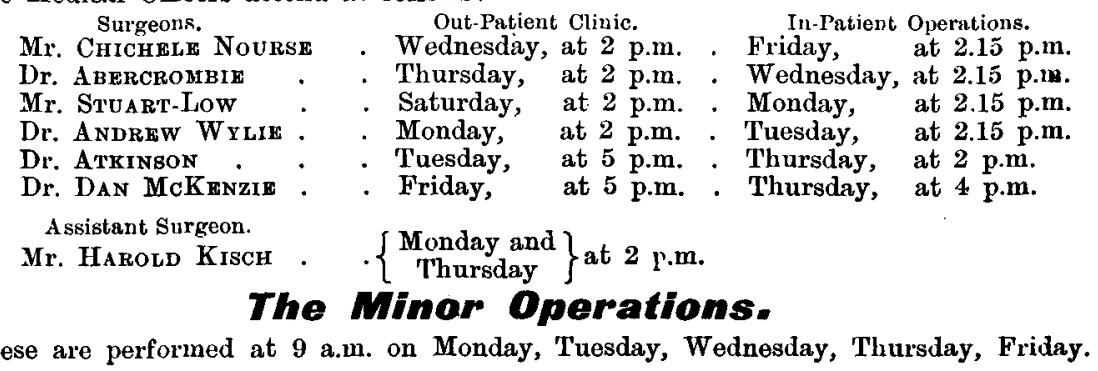

3.

The In-Patient Department. Major Operations.

These take place at 2 o'clock on Monday, Tuesday, Wednesday, 'l'hursday, Friday.

The list of operations is to be seen on the notice board in the Out-patient Consulting Room.

\section{Lectures and Demonstrations.}

Courses of Practical Instruction are given throughout the year by Members of the Staff, on Tuesdays and Fridays, at 3 p.m. punctually.

The Courses consist of two classes twice a week devoted to Anatomy, Pathology, Diagnosis and Treatment of the special diseases dealt with at the Hospital. They may be joined at any time.

A Surgical Anatomy and Operative Surgery Class is held when desired. The teaching is practical and demonstrative, and is illustrated by diagrams, models, specimens and instruments.

\section{The Pathological Laboratory}

Is at all times available to students. Dr. Wyatt Wingrave, Pathologist to the Hospital, is in attendance daily at 3 p.m.

\section{Clinical Assistants}

Are appointed from among those gentlemen who have enrolled themselves for attendance on the practice of the hospital.

Further particulars may be had on application to the Dean.

\section{Fees.}

\begin{tabular}{|c|c|}
\hline Course of Practical Instruction & with attendance at clinics \\
\hline Operative Surgery Class" & $\begin{array}{lll}\ldots & \ldots & \ldots\end{array}$ \\
\hline
\end{tabular}

For attendance on the practice of the Hospital (Clinical Assistants)-

\begin{tabular}{|c|c|c|c|}
\hline Three months & & & ineas. \\
\hline Six & & 8 & - \\
\hline Perpetual ticket & ... & 10 & " \\
\hline
\end{tabular}

Clinical dssistants are admitted to the Practical Course Free.

WYATT WINGRAYE, M.D.,

Dean,
RICHARD KERSHAW, Secretary Superintendent. 
'. . . the best, most instructive and useful Journal going.'
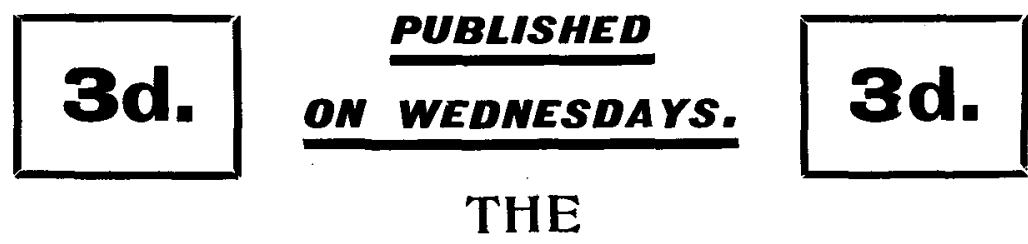

\section{CLINICAL JOURNAL}

A WEEKLY RECORD OF CLINICAL MEDICINE \& SURGERY

\section{With their Special Branches.}

THE CLINICAL JOURNAL was founded in 1892 with the object of SPECIALLY REPORTING and publishing CLINICAL LECTURES given by the leading Physicians and Surgeons of the day-Lectures for the most part delivered at the Hospitals to a few score of Students and quite lost to the General Practitioner who, however much he may desire to keep himself in touch with the progress of the times, is usually unable to attend.

Appreciation of this enterprise is shown by the present position of the Journal, its increasing circulation throughout the world, and the numerous letters received from subscribers.

New subscribers are strongly recommended to secure the BACK YOLUMES. It may be confidently asserted that no collection of Lectures more reliable and interesting, nor material of greater practical value, is available to the General Practitioner.

\section{Subscribers write:-}

"I consider of all the Medical Journals the 'Clinical Journal' is of the greatest use to the busy general practitioner."

"The fact is the Journal contains the very sort of article the country practitioner wants."

“. . . the Journal has been useful to me in deciding points, many of which are not in text-books."

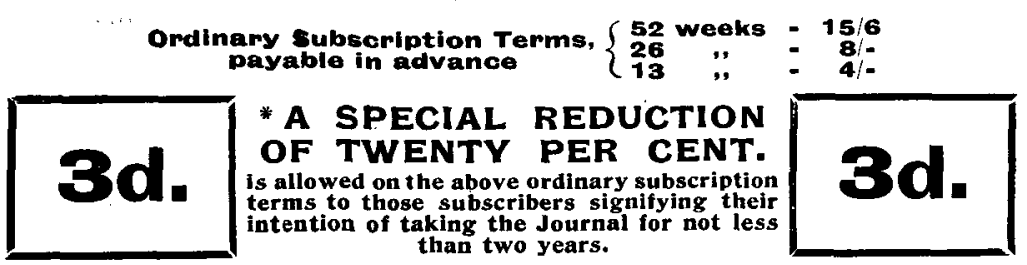

The Medicar Publishing Company, L.td., 23, Bartholomew Close, E.C. 


\section{MAYER \& MELTZER,}

Surgical Instrument Makers.

ESTABLISHED OVER FIFTY YEARS.
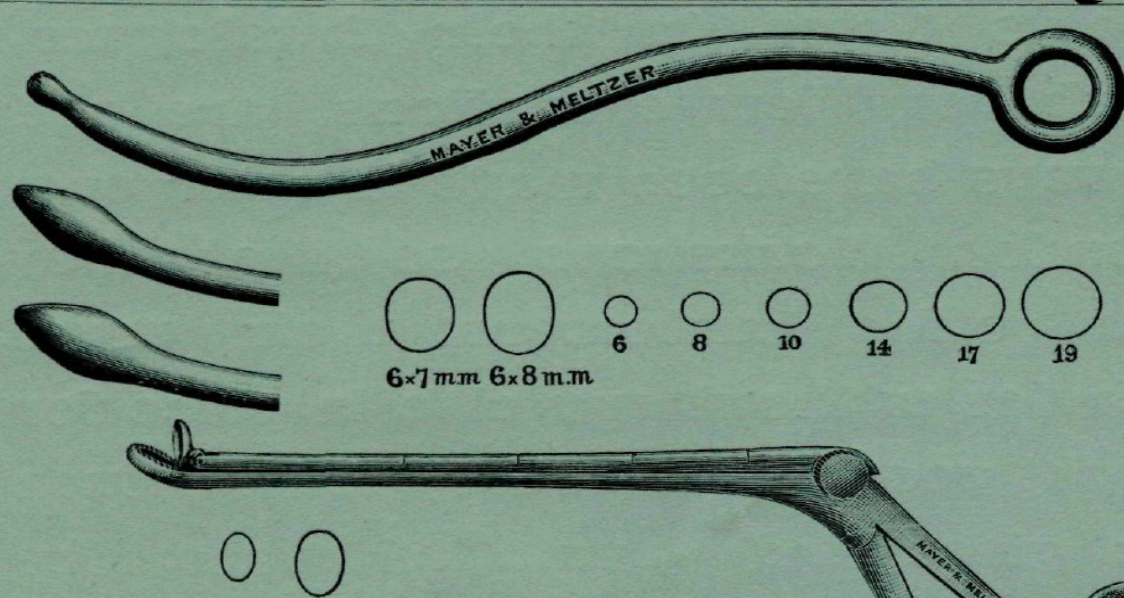

FULL SIZE
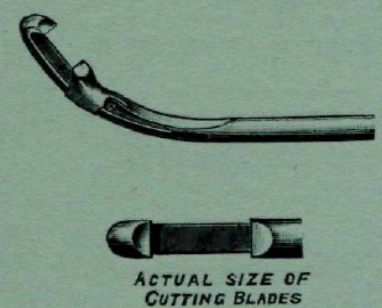

CUTTING BLADES

Instruments as used by Dr. Watson-Williams forl the Intra-Nasal Operation for Frontal

Sinus Suppuration.

(SEe JOURNAL OF LARYNGOLOGY, May, 1914.)

Full Particulars on application.

MAYER \& MELTZER, 71, GREAT PORTLAND ST., LONDON.

Branches:'MELBOURNE; CAPE TOWN; JOHANNESBURG. 


\section{MAYER \& MELTZER}

Wish to state that all the instruments listed in their Catalogues, with very few exceptions, are and always have been made in their own London Workshops, so that they can offer customers their usual service without any rise in price for such goods. In sundry lines, such as glass and enamelled ware, the manufacturers have advanced their prices, so that these must necessarily be raised in proportion. It is perhaps unnecessary to state that partners, capital and staff are entirely British.

MAYER \& MELTZER, Surgical Instrument MaKers.

ESTABLISHED OVER FIFTY YEARS.

71, Great Portland Street, LONDON. And at Melbourne, Cape Town, Johannesburg. 